U.S. Department of the Interior U.S. Geological Survey

\title{
The Effect of Chamber Mixing Velocity on Bias in Measurement of Sediment Oxygen Demand Rates in the Tualatin River Basin, Oregon
}

Water-Resources Investigations Report 03-4097

Prepared in cooperation with Clean Water Services

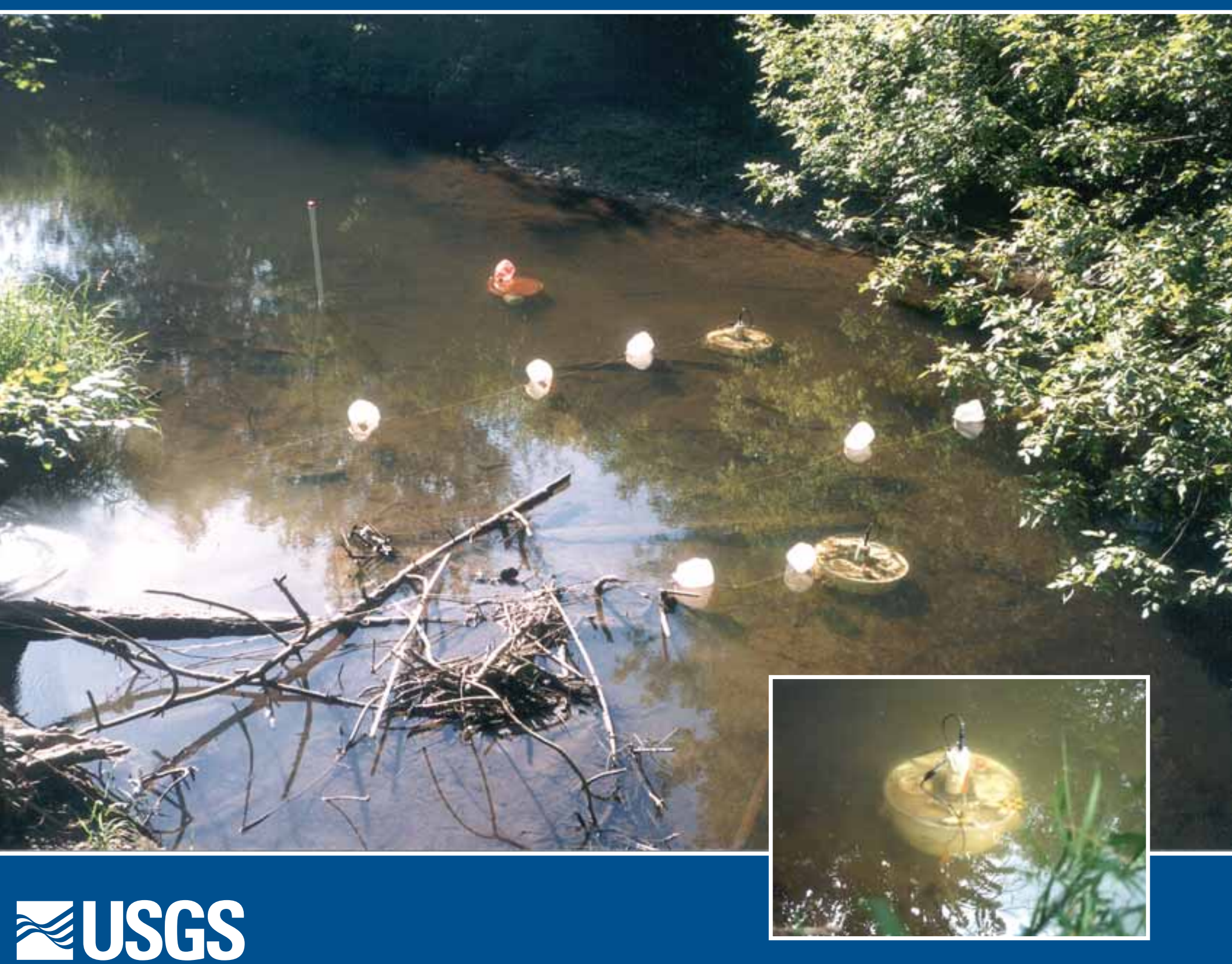




\section{Cover photograph:}

Sediment oxygen demand chambers deployed in Fanno Creek at Durham City Park, Durham, Oregon, July 15, 1996 (photograph by Stewart A. Rounds). 
U.S. Department of the Interior

U.S. Geological Survey

\section{The Effect of Chamber Mixing Velocity on Bias in Measurement of Sediment Oxygen Demand Rates in the Tualatin River Basin, Oregon}

\section{By MICELIS C. DOYLE and STEWART A. ROUNDS}

Water-Resources Investigations Report 03-4097

Prepared in cooperation with

Clean Water Services 


\section{THE INTERIOR}

GALE A. NORTON, Secretary

U.S. GEOLOGICAL SURVEY

CHARLES G. GROAT, Director

The use of trade, product, or firm names in this publication is for descriptive purposes only and does not imply endorsement by the U.S. Government.

For additional information:

Copies of this report may be purchased from:

District Chief

U.S. Geological Survey 10615 S.E. Cherry Blossom Dr.

USGS Information Services

Portland, OR 97216-3159

Box 25286, Federal Center

E-mail: info-or@usgs.gov

Denver, CO 80225-0286

Internet: http://oregon.usgs.gov

Telephone: 1-888-ASK-USGS

\section{Suggested citation:}

Doyle, M.C., Rounds, S.A., 2003, The effect of chamber mixing velocity on bias in measurement of sediment oxygen demand rates in the Tualatin River Basin, Oregon: U.S. Geological Survey Water-Resources Investigations Report 03-4097, $16 \mathrm{p}$. 


\section{CONTENTS}

Abstract ...

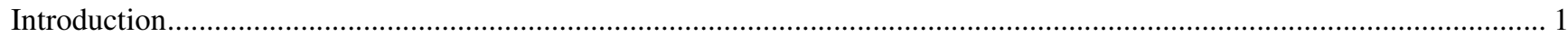

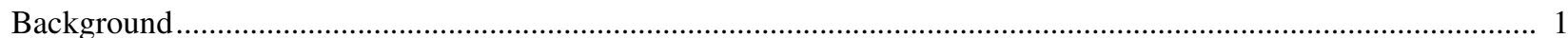

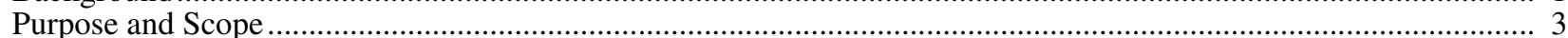

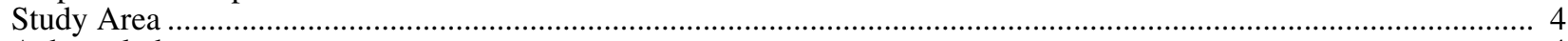

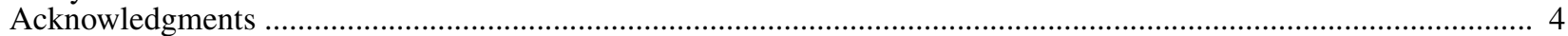

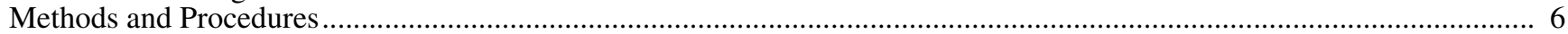

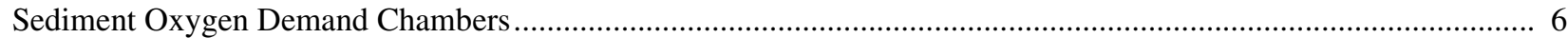

Sediment Oxygen Demand Chamber Deployment..................................................................................... 6

Calibration of Chamber Pump-Speed Setting to Velocity of Circulated Water................................................................ 6

Instream Chamber Circulation Velocity Experiments ........................................................................................... 7

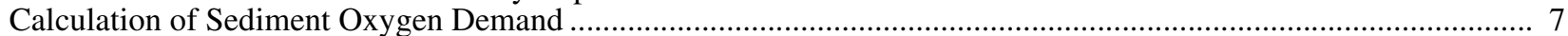

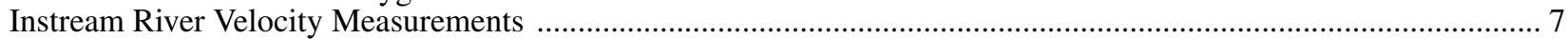

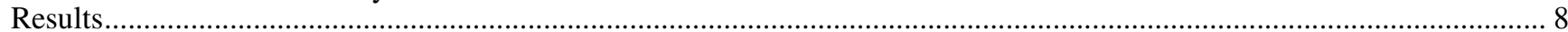

SOD Rates with Varying Chamber Circulation Velocities ................................................................................. 8

Effects of Velocity on Turbidity Measurements in Chambers ...................................................................................... 9

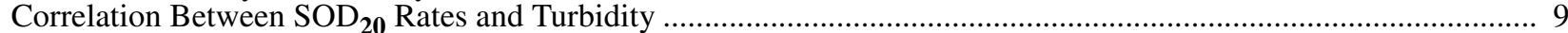

Velocity and Discharge in the Tualatin River during this Study and in 1992-96.................................................... 10

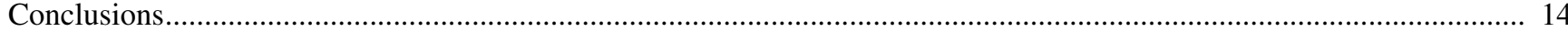

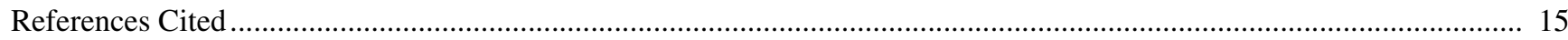

\section{FIGURES}

Figure 1. Diagrams showing (A) sediment oxygen demand processes and (B) cross-sectional view of sediment oxygen demand chamber deployed in riverbed................................................................................................................ 3

Figure 2. Idealized representation of the effects of chamber circulation velocity on in situ chamber

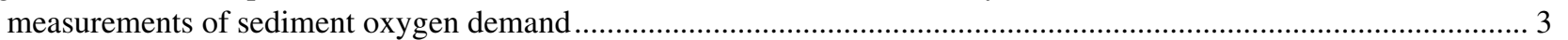

Figure 3. Map of Tualatin River Basin showing locations of sediment oxygen demand study sites............................... 5

Figure 4. Underside view of SOD chamber depicting $(A)$ the flow pattern produced by the diffusers

in their alignment during 1992-96 measurements and $(B)$ the flow pattern produced by the diffusers in their

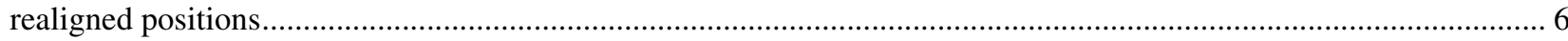

Figure 5. Example of a cross-sectional velocity profile obtained by an acoustic doppler current profiler

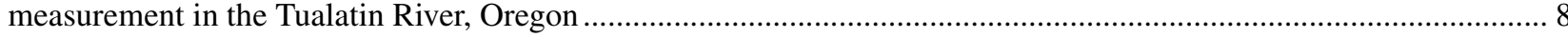

Figure 6. Relation of $\mathrm{SOD}_{\mathbf{2 0}}$ rates to chamber circulation velocity with diffusers in $(A)$ their original position and

$(B)$ their realigned position during instream chamber experiments at river mile 10 in the Tualatin River, Oregon ........9

Figure 7. Graphs showing average turbidity values with corresponding chamber mixing velocities obtained during chamber velocity experiments with diffusers in their (A) original alignment and (B) their realigned

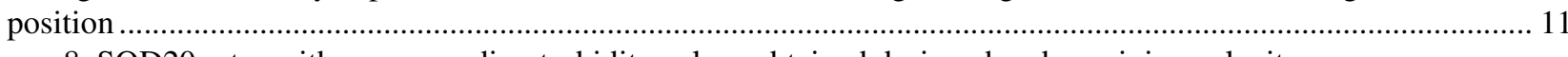

Figure 8. SOD20 rates with corresponding turbidity values obtained during chamber mixing velocity experiments with diffusers in $(A)$ their original position and $(B)$ their realigned position...

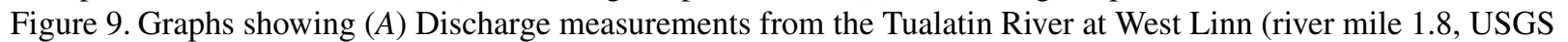
station number 14207500), (B) rainfall measured at the Clean Water Services Durham Treatment Facility (USGS station number 452359122454500), $(C)$ dissolved oxygen values measured in the Tualatin River at Oswego Dam (river mile 3.4, USGS station number 14207200), September 1-October 15, 2000

TABLES

Table 1. Calculated sediment oxygen demand rates corrected to 20 degrees Celsius $\left(\mathrm{SOD}_{\mathbf{2 0}}\right)$ and average turbidity at different chamber circulation velocities in the Tualatin River at river mile 10.................................................. 10

Table 2. Average near-bottom river velocity calculated from acoustic doppler current profiler readings at selected sites

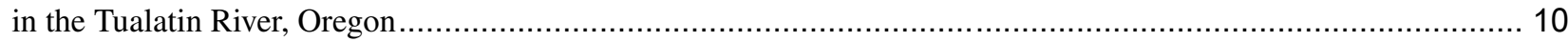

Fable 5. Strealm alscharge in the Tuataith kiver dumng sedment oxygen demand chamber ctrculation vetoctly

experiments in August 2000 and in November 2001 


\title{
The Effect of Chamber Mixing Velocity on Bias in Measurement of Sediment Oxygen Demand Rates in the Tualatin River Basin, Oregon
}

\author{
By Micelis C. Doyle and Stewart A. Rounds
}

\section{ABSTRACT}

Three sediment oxygen demand (SOD) measurement chambers were deployed in the Tualatin River near Tigard, Oregon, at river mile 10 in August 2000. SOD rates were calculated for three different circulation velocities during each chamber deployment. The SOD rate at each velocity was calculated from a graph of dissolved oxygen concentration versus elapsed time. An acoustic doppler current profiler (ADCP) was used to measure stream discharge and near-bottom water velocities in the Tualatin at river mile 10 and at two upstream locations. Measured river and chamber velocities were similar, indicating that results from the chambers were representative of instream effects.

At low to moderate chamber circulation velocities (less than about 7.5 centimeters per second), the measured SOD rate appeared to be only slightly affected by the circulation velocity, indicating that the measured rates reflect the rate of oxygen utilization by chemical and biological reactions in the sediment rather than the rate of physical transport of oxygen to the sediment-water interface. Above about 7.5 centimeters per second, however, the measured oxygen depletion rate was affected by the circulation velocity, as sufficient energy was generated within the chamber to resuspend bottom sediment, as evidenced by increased turbidity. The resuspended sediment particles contributed to the measured oxygen loss rate by increasing the surface area of decomposing material in contact with the water column, resulting in a measured SOD rate that was anomalously high. Two different alignments of the chamber circulation diffusers were tested. With both diffuser alignments, SOD rates were similar at circulation velocities low enough to avoid sediment resuspension.

This same resuspension effect probably exists in the Tualatin River during storm-runoff events following prolonged periods of low flow, when increased stream velocity may result in the resuspension of bottom sediments. The resuspension causes increased turbidity and increased oxygen demand, resulting in lower instream dissolved oxygen concentrations.

\section{INTRODUCTION}

\section{Background}

The U.S. Geological Survey (USGS) began measuring sediment oxygen demand (SOD) in the Tualatin River in the low-flow season (May through October) of 1992. During the period 1992-1996, more than 125 measurements of SOD were made at 20 tributary and main-stem sites in the Tualatin River Basin. Results from SOD measurements in the Tualatin Basin (Rounds and Doyle, 1997) demonstrated that SOD was a dominant process affecting dissolved oxygen (DO) throughout the lower Tualatin River (Kelly, 1997). SOD measurements were critical to USGS hydrologists and Tualatin River Basin water-quality management agencies in developing a 
better understanding of the river's DO budget (Kelly, 1997; Rounds and others, 1999).

SOD is an important consumer of DO in the Tualatin River, typically utilizing more DO than any other single process during the low-flow season (Rounds and others, 1999). DO is consumed by aquatic organisms, chemical reactions in the water column, and the decomposition of organic material in the sediment, as shown in figure 1(A). Particularly during the warm summer months (low-flow periods), oxygen consumption may exceed the rate at which it is replenished by photosynthesis or from the atmosphere, causing the DO concentration to decrease to a level that may jeopardize the health of aquatic organisms.

Consequently, it is important to quantify SOD rates in the Tualatin River, and errors in their measurement, in order to understand the processes leading to periodic low DO levels in the river.

SOD consists of many related biological and chemical processes. The primary contributing factor to SOD is the deposition and subsequent decomposition of organic matter from the watershed and from algae growing in the water column. This organic matter decomposes by way of oxidation-reduction reactions at or near the sediment-water interface. These reactions can be abiotic, but most typically are facilitated by microbial organisms. The SOD rate depends on the quantity and type of organic matter in the near-surface sediments. In addition, SOD may depend on the rate that soluble reduced organic matter is transported up to the sediment-water interface and the rate that DO from the water column is transported to the sediments (Whittemore, 1986).

SOD rates can be measured either in a laboratory setting or in situ. The laboratory method involves collection of bottom sediment and subsequent measurement of SOD in a controlled laboratory environment. Some proponents of this method prefer it because laboratory measurements facilitate experiment replication and allow additional factors such as temperature change and nutrient and metals release to be considered (Longaker and Poppe, 1986). One of the primary disadvantages of this method, however, is that the removal of bottom sediments from a water body for laboratory experiments results in disturbance of those sediments. Exertion of oxygen demand may be changed by this disturbance, which is not reversible (Whittemore, 1999). The in situ method involves the collection of data onsite, directly from the water body. Although both methods have their advantages and disadvantages, the in situ technique appears to be the better approach for measuring SOD because it minimizes the disturbance of bottom-sediment layers and the associated biological communities. While the in situ method may be the most accurate method for measuring sediment oxygen demand, it requires considerable lead time, special equipment, and training for the field crews (Hatcher, 1986).

Accurate and representative in situ measurements are best obtained when SOD chambers are designed to simulate natural river processes that affect the SOD rate. Two of the most significant factors influencing SOD are the temperature and velocity of the water overlying the sediment. The rates of abiotic and organic oxidation reactions are temperaturedependent; thus the rate of SOD is temperaturedependent. Many currently used formulations for this temperature dependence approximate the Q10 or van't Hoff rule, which states that the rate of biological reactions approximately doubles with each 10-degree (Celsius) rise in temperature (McDonnell and Hall, 1969).

Several studies have been undertaken to quantify the effect of water velocity on measured SOD rates. Whittemore (1986) measured a doubling of SOD as the velocity of water in the SOD chamber was doubled. Other researchers have measured SOD in controlled laboratory experiments and noted a linear increase in the SOD rate as the chamber velocity was increased (Mackenthum and Stefan, 1998). Still others have shown a significant effect of flow velocity on SOD using a flow-through system in a laboratory or a closed chamber in situ. SOD was shown to increase linearly with velocity at low velocities, but it becomes independent of velocity at higher velocities (Nakamura and Stefan, 1994). The degree to which the measured SOD is affected by velocity can be attributed to DO concentrations in the river, environmental conditions, and the composition and concentration of the chemical and biological constituents involved in the reactions that consume dissolved oxygen.

Some researchers have suggested that the oxygen loss rate measured with in situ chambers at low velocities reflects the physical transport rate of oxygen from the overlying water to the sediment-water interface rather than the actual maximum rate of oxygen consumption by reactions occurring in that sediment (Parkhill and Gulliver, 1997). If this were the case, then an increase in the chamber circulation velocity would cause a corresponding increase in the oxygen loss rate at the sediment-water interface. At a 


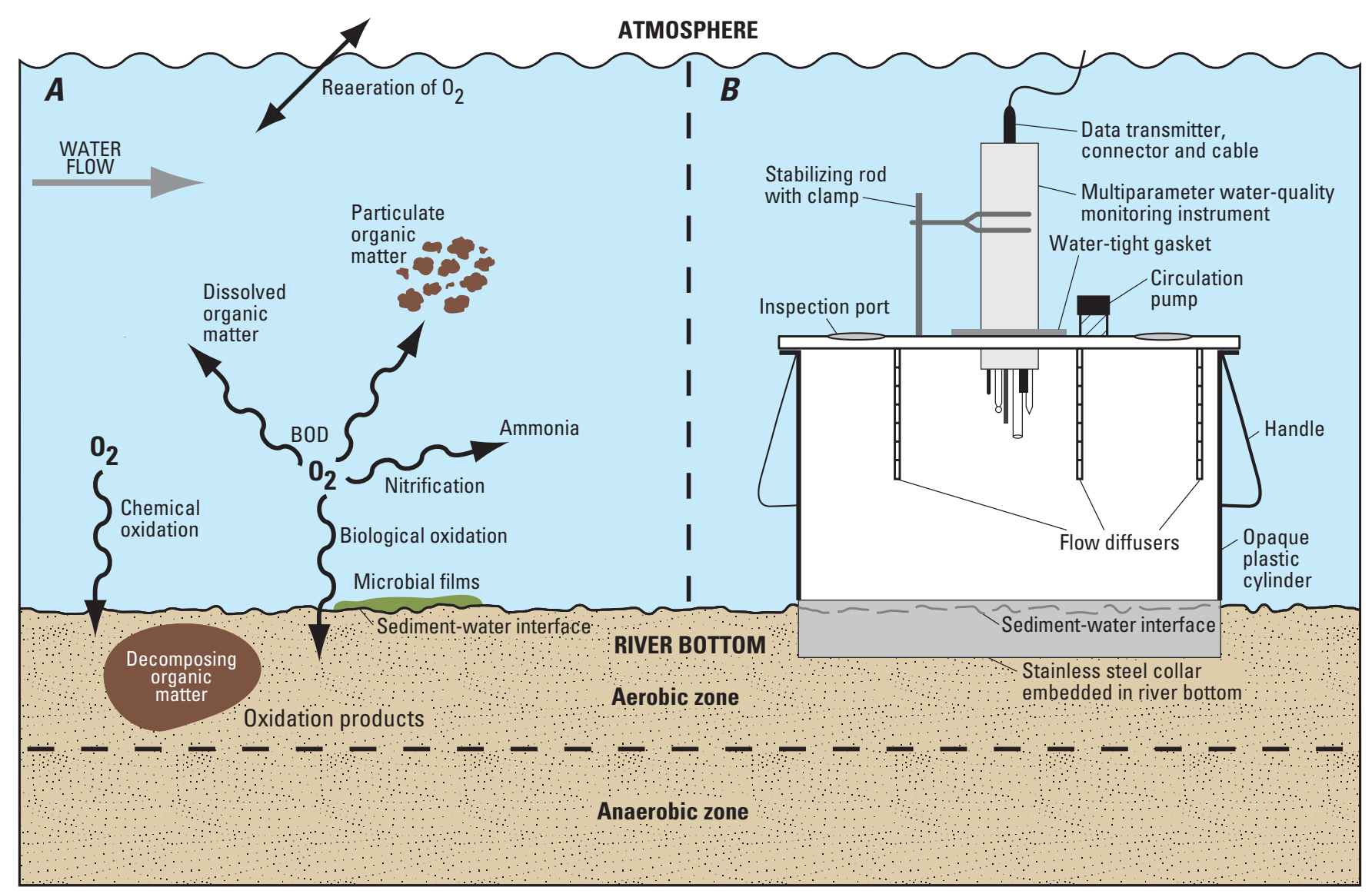

Figure 1. Diagrams showing (A) sediment oxygen demand processes and (B) cross-sectional view of sediment oxygen demand chamber deployed in riverbed.

high enough mixing rate, the physical transport rate would become faster than the rate of oxygen consumption in the sediments, and the measured oxygen loss rate would reflect the rate of oxygen utilization by chemical and biological reactions at the sediment-water interface (fig. 2).

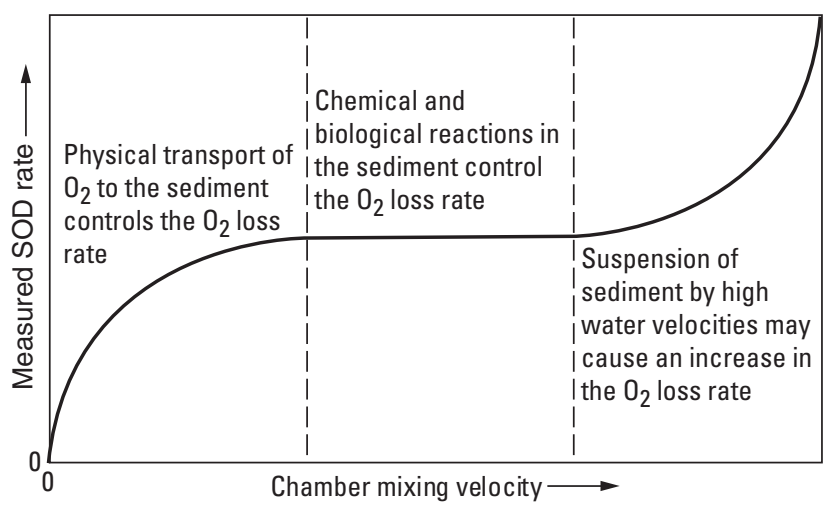

Figure 2. Idealized representation of the effects of chamber circulation velocity on in situ chamber measurements of sediment oxygen demand. At very low chamber circulation velocities, oxygen transport limitations may affect the measurement, while at high chamber circulation velocities suspension of sediment can bias the measurement.

\section{Purpose and Scope}

Sediments are known to be a large sink of dissolved oxygen in the meander and reservoir reaches of the Tualatin River (Kelly, 1997). While many SOD measurements were made from 1992 to 1996 to quantify its importance, little work was done to determine how the circulation velocities inside the SOD chambers might have affected these measurements. This report describes experiments to quantify the variability of SOD measurements as a function of chamber circulation velocity at a typical depositional area in the lower Tualatin River. Specifically, the report describes the effect of water velocity on SOD as the velocity in the chamber is changed over the same parcel of bottom sediment, in order to establish bounds on the relationship described in figure 2. These data will be used to determine how SOD rates measured with the chambers reflect the SOD expressed in the Tualatin River, whether SOD in the river varies with changes in near-bottom velocity, and whether a bias exists in the measured SOD rate if the chamber 
circulation velocity does not match the river's nearbottom water velocity.

This report is designed for use by river managers and regulatory agencies in their efforts to maintain the water quality of the Tualatin River in a condition suitable for recreational use and to sustain and enhance conditions for aquatic life. It is also intended for use by researchers and water resource managers who are interested in the dynamics of DO in aquatic ecosystems and the successful collection and incorporation of SOD data into water-quality studies.

\section{Study Area}

The Tualatin River is a tributary to the Willamette River and is located west of downtown Portland, Oregon (fig. 3). The Tualatin River Basin has an approximate area of 712 square miles and contains dense forests in the uppermost, mountainous areas, agricultural lands in the valley bottom, and a rapidly expanding urban area with over 400,000 people in the lower basin. The Tualatin River Basin is bounded by the Coast Range Mountains to the west and northwest, the Chehalem Mountains and Parrett Mountain to the south, and the Tualatin Mountains to the east and northeast (fig. 3). The Tualatin River drains most of Washington County and small parts of Multnomah, Clackamas, Yamhill, Tillamook, and Columbia Counties.

The Tualatin River can be divided into four ecologically distinct reaches: a headwater reach (river mile 79-55), a meander reach (river mile 55-30), a backwater reach (river mile 30-3.4), and a riffle reach (river mile 3.4-confluence with the Willamette River).

In its headwater reach, the Tualatin River is a high-gradient mountain stream (average gradient of about 74 feet per mile) with correspondingly high water velocities. The character of the river throughout most of this reach is that of a pristine mountain stream with few depositional areas for fine sediments.

The meander reach is a 25-mile-long section that begins just downstream of the confluence with Gales Creek (fig. 3). The stream gradient in this section of the river decreases to about 1.3 feet per mile, and streamflow increases due to inputs from Dairy and Rock Creeks. Within this meandering reach, the channel widens slightly and water velocities decrease. During the low-flow season (May to October), depositional zones form in some areas of this reach and extensive amounts of organic material—fine sediment from forest, agriculture, and urban lands-accumulate on the streambed in many sections. The larger volumes of organic material on the streambed and the lower reaeration rates than in the headwater reach lead to a slight degradation of water quality, in terms of DO demand, but serious DO depletion generally does not occur.

The backwater (or reservoir) reach begins at river mile 30 and extends to a 4-foot low-head dam at river mile 3.4. The stream gradient is essentially flat throughout (about 0.08 feet per mile), and the river deepens and slows as the water moves through this reach. The streambed is uneven and forms occasional deep pools (15-18 feet) that can thermally stratify during periods of low flow and warm weather. Large deposits of organic material collect in depositional zones during the low-flow season, resulting in a significant SOD that is the dominant loss process for DO throughout this reach of the river (Kelly, 1997).

The riffle reach begins below the low-head dam (river mile 3.4 to the Tualatin River's confluence with the Willamette River). A narrowing channel, a steep gradient of about 13 feet per mile, and increased water velocities characterize this reach. Comparatively little deposition occurs in this part of the river and many rocks in the streambed are exposed. This reach tends to reaerate low-DO water coming from the reservoir reach.

\section{Acknowledgments}

This investigation benefited greatly from the assistance of many people. The authors are grateful to Tirian Mink for his assistance in the construction of the SOD chambers, Ray Hoy for his help during the SOD chamber velocity determinations, Roy Wellman for his timely and valuable assistance in obtaining riverbottom velocity data, Dennis Lynch for his assistance and guidance during the fieldwork portion of this study, and Domanic Thomas for his help in acquiring research literature from Oregon State University. We gratefully acknowledge the scientific collaboration and financial contributions of Clean Water Services (CWS) of Washington County and the assistance of Janice Miller (CWS) and Bernadine Bonn (CWS). 


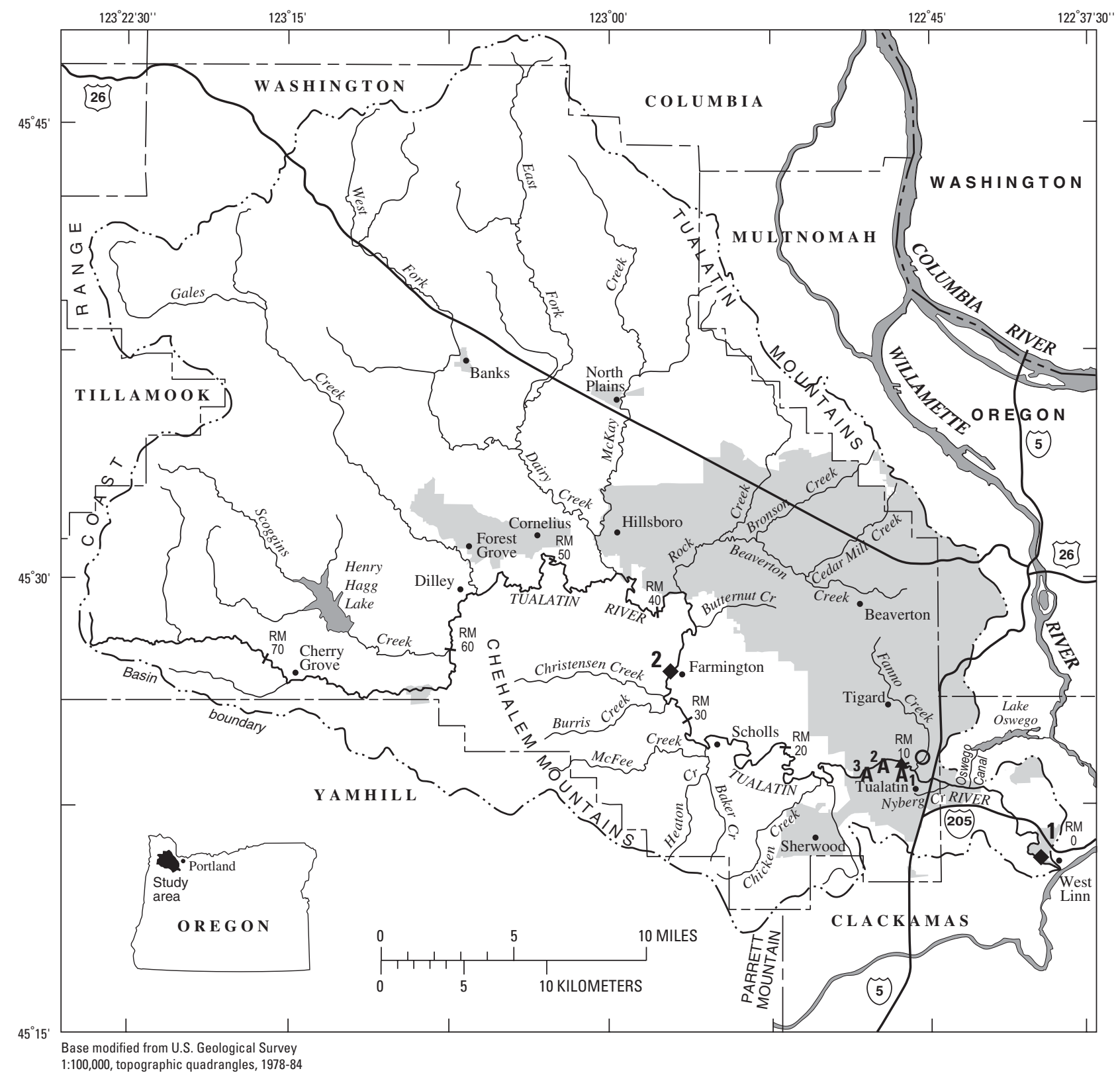

\section{EXPLANATION}

Sampling site

Tualatin River at Cook Park near Tigard, Oregon

A Acoustic Dopler Current Profiler measurement site

1 River mile 10

2 River mile 11.0

3 River mile 11.7

\section{Gaging station}

1 Tualatin River at West Linn- Operated by U.S. Geological Survey (14207500)

2 Tualatin River at Farmington Road-

Operated by Oregon Water

Resources Department (14206500)

O Durham Wastewater Treatment Plant (RM 9.3)

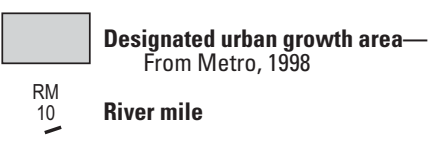

signated urban growth area-

(a) nile

Figure 3. Map of Tualatin River Basin showing locations of sediment oxygen demand study sites. 


\section{METHODS AND PROCEDURES}

\section{Sediment Oxygen Demand Chambers}

The chambers used in this study to measure SOD in the Tualatin River (fig. 1) isolate a known volume of water over a known area of bottom sediment. Water inside the chambers is recirculated over the bottom sediments and the loss of oxygen is monitored over time. The SOD chambers used in this investigation and also during 1992-96 are open-bottomed, opaque plastic cylinders that are designed to seat and seal on the bottom of the stream. The lower part of the chamber has a stainless steel collar to assist in bed sediment penetration and provides a good seal to the river bottom when seating the chambers.

\section{Sediment Oxygen Demand Chamber Deployment}

When deploying each chamber for SOD measurements, the inspection ports are opened and the chamber is slowly and carefully pushed into the river bottom to minimize the disturbance of the bottom sediments. Once seated, each chamber isolates about 52 liters of river water that is then circulated over 0.225 square meters of bottom sediment. During the measurement period, water in the chamber is circulated by a bilge pump, which is powered by a 12 -volt rechargeable gel-cell battery connected to a rheostat. Water is withdrawn from the chamber by the pump and then injected back into the chamber through three diffuser tubes (fig. 1B); this design allows for good mixing of the isolated water in the chamber with minimal suspension of the bottom sediments. Detailed procedures for SOD chamber deployment and use are described by Rounds and Doyle (1997).

\section{Calibration of Chamber Pump-Speed Setting to Velocity of Circulated Water}

Chamber velocities were measured at various pump settings with the flow diffusers (figs. 1 and 4) in two different alignments: their original alignment (same orientation used for the SOD measurements made from 1992 to 96) and in a realigned position. In their original position, the diffusers are directed in a manner such that mixing exists, and the discharges from the three diffusers create random flow directions inside the chamber. In the realigned position, the diffusers generate a circular flow pattern within the chamber; this was done so that SOD measurements for this experiment could be obtained using a wider range of chamber circulation velocities. In most cases, the realigned diffuser orientation resulted in an increased chamber velocity compared to the original diffuser alignment at the same pump setting.
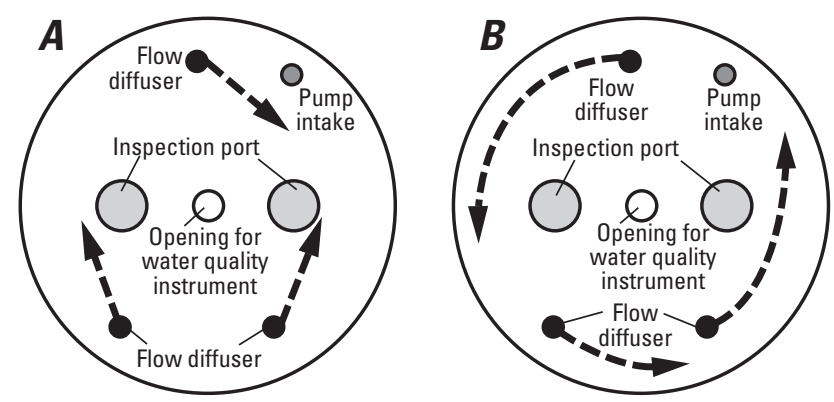

Figure 4. Underside view of SOD chamber depicting $(A)$ the flow pattern produced by the diffusers in their alignment during 1992-96 measurements and $(B)$ the flow pattern produced by the diffusers in their realigned positions.

A rheostat connected to the battery powering the pump for each chamber was used to vary the pump speed, resulting in an increase or decrease in chamber circulation velocity. Chamber velocities were determined at various pump speed settings with diffusers in their original and realigned positions. The following steps were used to determine the water velocity within each chamber at each pump speed setting:

- A radial line was drawn along the inside top of each chamber and measurement points (measured from the center of each chamber) were drawn at 1-inch intervals along the radial line.

- In a laboratory setting, the SOD chambers were inverted (open end up) and filled with tap water.

- For the two orientations of the diffusers and each rheostat setting, the water velocity was measured by timing a small track of rhodamine dye (injected with a pipette) once around the chamber. Injections were made along several concentric flow paths in order to calculate an average velocity at each injection point.

- An overall average chamber circulation velocity was calculated for each SOD chamber.

Chamber velocity determinations were videotaped so that procedures and measurements could be reviewed for accuracy. 


\section{Instream Chamber Circulation Velocity Experiments}

SOD chambers were deployed in the Tualatin River near Tigard, Oregon at river mile 10. Three chambers were deployed at the site according to procedures outlined in the "SOD Chamber Deployment" section. After the inspection ports were sealed with the water circulating inside of the chamber, each pump was set to the lowest (predetermined) rheostat setting. In order to reduce the potential of suspending bottom sediments, the pump speed was increased after a minimum 1-hour data-logging period at the preceding (lower) pump speed setting. SOD rates were calculated at three rheostat settings: low, medium and high. The following day, the chambers were redeployed on different parcels of bottom sediments, with the SOD chamber diffusers in the realigned position. The diffusers were realigned to promote a circular flow pattern and, more importantly, to provide a greater range of chamber circulation velocities. The SOD rate for each pump speed was calculated from a graph of dissolved oxygen concentration versus elapsed time.

\section{Calculation of Sediment Oxygen Demand}

Methods used to calculate SOD in this study were similar to those used by Rounds and Doyle (1997), except that during the velocity experiments, the multiparameter instruments inside the chambers were allowed to $\log$ data for a minimum of 1 hour rather than the minimum of 2 hours for previous Tualatin Basin SOD studies. The SOD rate is calculated from a graph of DO concentration in the chamber versus time. The slope of the oxygen depletion line is determined through linear regression. The following equation is used to calculate the SOD rate:

$$
\operatorname{SOD}_{T}=1.44 \frac{V}{A} b
$$

where $S O D_{T}$ is the sediment oxygen demand rate in grams of oxygen per square meter per day $\left(\mathrm{g} \mathrm{O}_{2} / \mathrm{m}^{2} /\right.$ day) at water temperature $T, b$ is the slope of the oxygen-depletion curve in milligrams per liter per minute, $V$ is the volume of the chamber in liters, $A$ is the area of bottom sediment covered by the chamber in square meters, and 1.44 is a units-conversion constant (Murphy and Hicks, 1986).

Measured SOD rates were corrected to 20 degrees Celsius using a Q10 (or van't Hoff) equation:

$$
S O D_{20}=\frac{S O D_{T}}{1.065^{(T-20)}}
$$

where $S O D_{20}$ is the SOD rate at 20 degrees Celsius, and $T$ is the water temperature during measurement in degrees Celsius (Thomann and Mueller, 1987). This correction does not hold for temperatures less than 10 degrees Celsius; however, water temperatures exceeded 20 degrees Celsius at all times during this study.

\section{Instream River Velocity Measurements}

An acoustic doppler current profiler (ADCP) was used to measure stream discharge and estimate near-bottom water velocities in the Tualatin River. These velocities were estimated to allow a comparison between river and chamber velocities and to obtain a range of actual near-bottom river velocities.

An ADCP works by emitting a sound at a fixed frequency and analyzing the frequency and time delay of the sound echoes reflecting from particles moving with the water (Gordon, 1996).

One of the advantages of using an ADCP as compared to a current meter is its ability to measure velocity in a vertical profile. The velocity profile is divided into uniform "depth cells" or "bins" (fig. 5). The depth cells from ADCP measurements are uniformly spaced and measure average velocity over the depth range of each cell.

ADCP measurements obtained in the deepest $6 \%$ of the water column can be inaccurate due to scatter from an irregular bottom surface, which biases the velocity measurement towards a lower reading. However, because velocity increases predictably with distance above the bed (Leopold and others, 1964), the bottom velocities can be estimated based on principles of the standard velocity profile (Rantz and others 1982). 


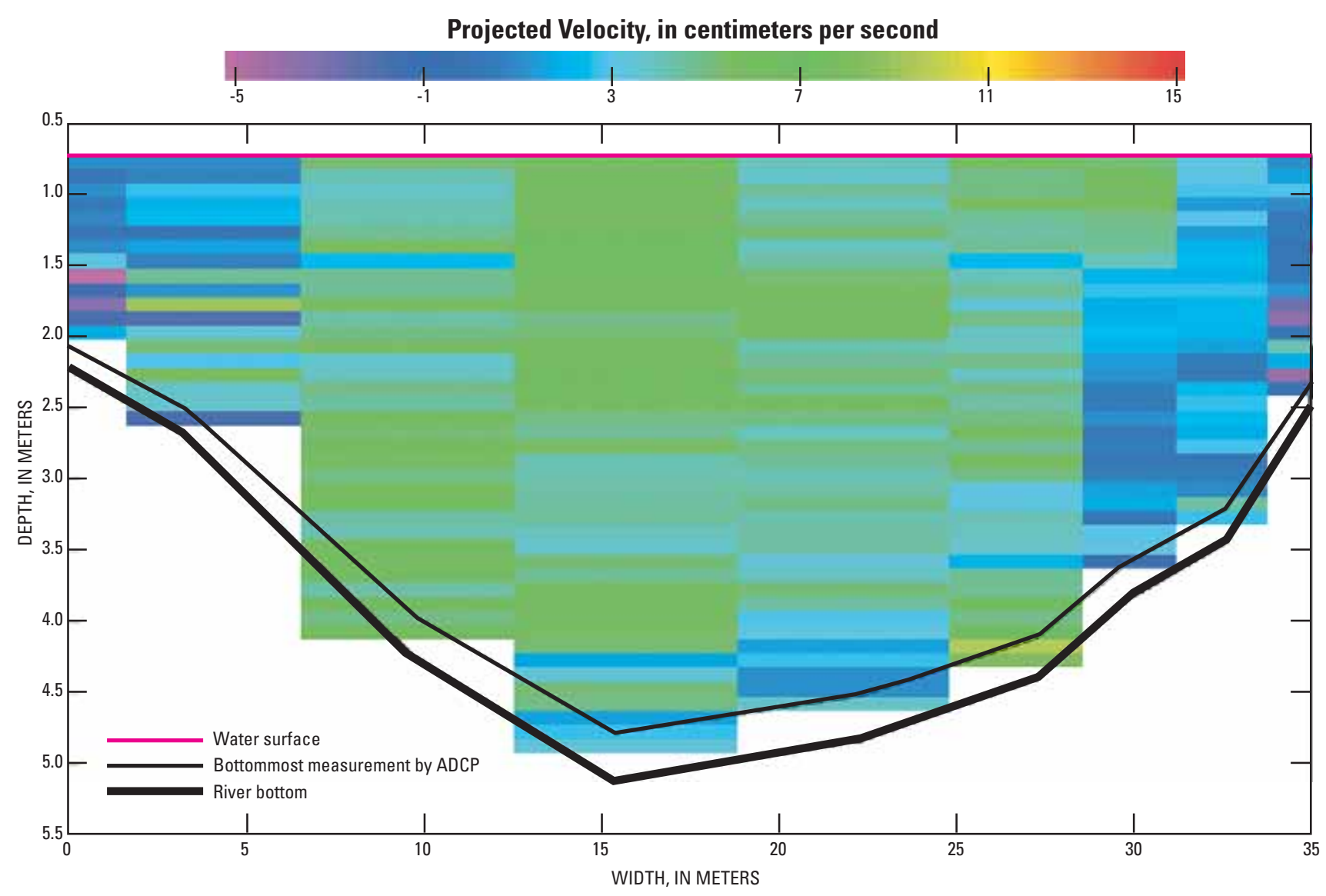

Figure 5. Example of a cross-sectional velocity profile obtained by an acoustic doppler current profiler (ACDP) measurement in the Tualatin River, Oregon.

\section{RESULTS}

\section{SOD Rates with Varying Chamber Circulation Velocities}

The extent to which the SOD rate varied with near-bottom water velocity was evaluated from experiments that controlled the chamber circulation velocity over the same area of bottom sediment.

Results and related information from the SOD chamber circulation velocity experiments are listed in table 1 .

Figure 6 shows the measured $\mathrm{SOD}_{20}$ rates as a function of chamber circulation velocity with the diffusers in their original and realigned positions. Each SOD chamber deployment in figure 6 depicts $\mathrm{SOD}_{20}$ rates from each experiment at various velocities and over the same parcel of bottom sediment. For example, velocities in the original diffuser alignment for chamber 1 ranged from $0.6 \mathrm{~cm} / \mathrm{sec}$ (centimeters per second) to $3.8 \mathrm{~cm} / \mathrm{sec}$ with resulting $\mathrm{SOD}_{20}$ rates of
$1.58 \mathrm{~g} / \mathrm{m}^{2} /$ day (grams of $\mathrm{O}_{2}$ per square meter per day) to $1.84 \mathrm{~g} / \mathrm{m}^{2} /$ day, respectively. In this chamber deployment, a six-fold increase in velocity was imposed with only a $0.26 \mathrm{~g} / \mathrm{m}^{2} /$ day increase in $\mathrm{SOD}_{20}$ rate (an increase of about 16\%).

Increases in chamber circulation velocity (by factors of 2 to 8 for all of the experiments) generally did not result in SOD rate increases that were proportional to the increases in chamber circulation velocity. Only slight increases in the SOD rate occurred when chamber velocities ranged from 0.6 to $7.4 \mathrm{~cm} / \mathrm{sec}$ with the diffusers in their original positions (fig. 6A). The elevated turbidity during the deployment of chamber 2, with a circulation velocity of $7.6 \mathrm{~cm} / \mathrm{sec}$ (fig. 6A, table 1), indicated a higher concentration of suspended material, which likely contributed to the higher DO loss rate (see fig. 2). SOD rates did not increase up to circulation velocities of $9.5 \mathrm{~cm} / \mathrm{sec}$ with the diffusers in the realigned position. Further, SOD rates were similar with the diffusers in both alignments. 


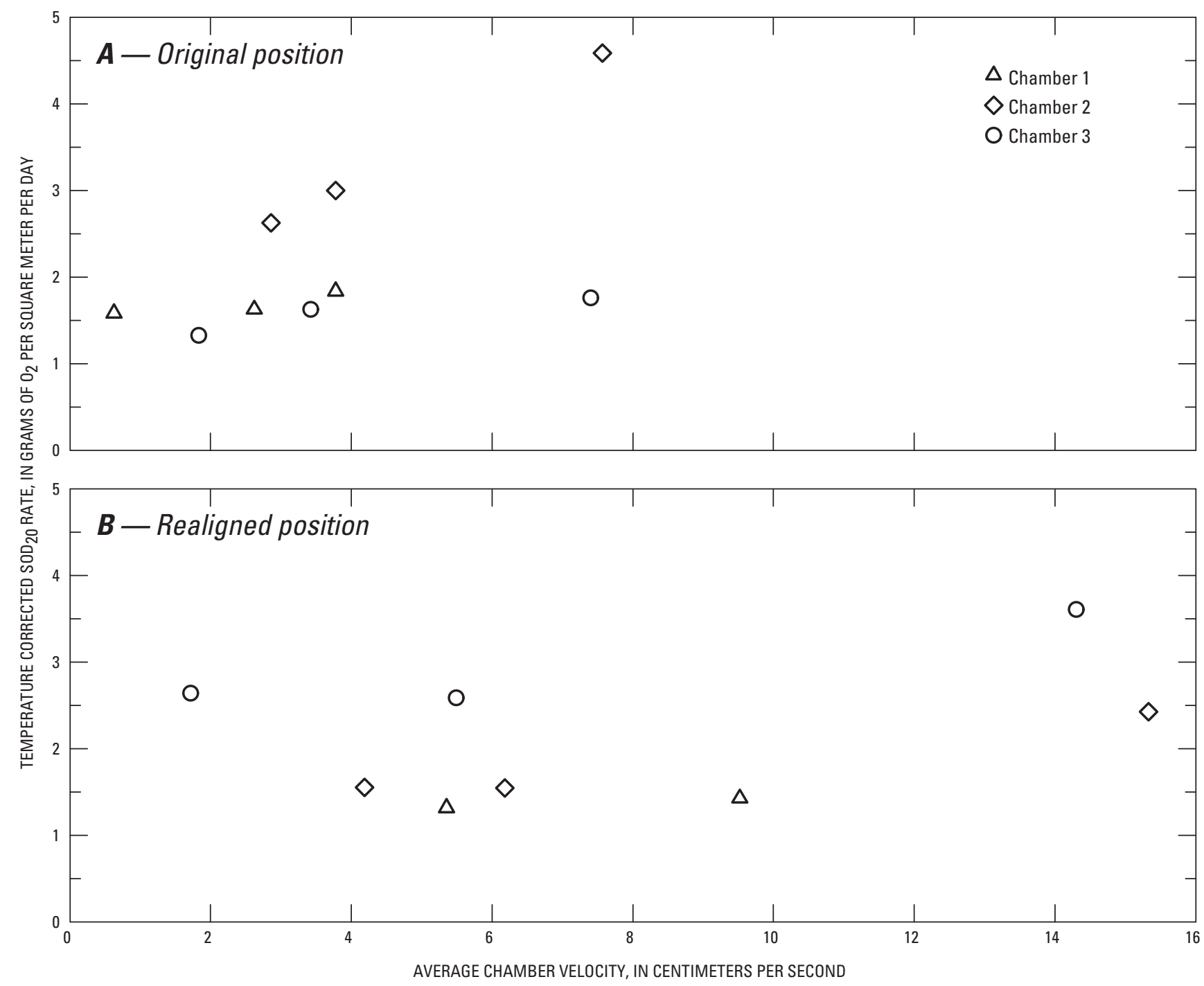

Figure 6. Relation of $\mathrm{SOD}_{20}$ rates to chamber circulation velocity with diffusers in $(A)$ their original position and $(B)$ their realigned position during instream chamber experiments at river mile 10 in the Tualatin River.

\section{Effects of Velocity on Turbidity Measurements in Chambers}

During the experiments, turbidity was measured to detect any resuspension of bottom material with increased chamber velocity. A mean turbidity value (over the duration of the experiment) was calculated for each experiment (table 1). Chamber circulation velocity and site-to-site variability in sediment characteristics account for the differences in average turbidity readings among chambers.

In each of the experiments, the average turbidity did not change substantially as the circulation velocity was increased in the range of $0.6-6.2 \mathrm{~cm} / \mathrm{sec}$. However, chamber velocities greater than $7.4 \mathrm{~cm} / \mathrm{sec}$ with the diffusers in their original position resulted in elevated turbidity values, ranging from over $90 \%$ to $600 \%$ higher (table 1, fig. 7A). When the diffusers were positioned to produce a more circular flow, there was no apparent sediment resuspension at velocities of up to $9.5 \mathrm{~cm} / \mathrm{sec}$.

\section{Correlation Between $\mathrm{SOD}_{20}$ Rates and Turbidity}

Except for the experiments with chamber 1, chamber velocities were increased to a point where the measured turbidity values indicated that bottom sediments were resuspended in the water column. In each of these cases of increased turbidity levels, a resultant increase in the $\mathrm{SOD}_{20}$ rate was measured 
Table 1. Calculated sediment oxygen demand rates corrected to 20 degrees Celsius $\left(\mathrm{SOD}_{20}\right)$ and average turbidity at different chamber circulation velocities in the Tualatin River at river mile 10

[cm/sec, centimeters per second; $\mathrm{g} \mathrm{O}_{2} / \mathrm{m}^{2} /$ day, grams of oxygen per square meter per day; NTU, nephelometric turbidity units]

\begin{tabular}{|c|c|c|c|c|c|c|c|}
\hline $\begin{array}{c}\text { Chamber } \\
\text { deployment } \\
\text { number }\end{array}$ & Chamber & $\begin{array}{c}\text { Flow diffuser } \\
\text { alignment }\end{array}$ & Pump setting & $\begin{array}{l}\text { Average } \\
\text { chamber } \\
\text { velocity } \\
\text { (cm/sec) }\end{array}$ & $\begin{array}{c}\text { Temperature } \\
\text { corrected SOD } \\
\left(\mathrm{g} \mathrm{O}_{2} / \mathrm{m}^{2} / \mathrm{day}\right)\end{array}$ & $\begin{array}{c}\text { Estimated error in } \\
\text { SOD measurement } \\
\left(\mathrm{g} \mathrm{O}_{2} / \mathrm{m}^{2} / \text { day }\right)\end{array}$ & $\begin{array}{c}\text { Average } \\
\text { turbidity } \\
\text { (NTU) }\end{array}$ \\
\hline 1 & 1 & Original & Low & 0.6 & 1.58 & 0.07 & 10 \\
\hline 1 & 1 & Original & Medium & 2.6 & 1.63 & .08 & 9.0 \\
\hline 1 & 1 & Original & High & 3.8 & 1.84 & .22 & 11 \\
\hline 2 & 1 & Realigned & Medium & 5.4 & 1.32 & .16 & 6.1 \\
\hline 2 & 1 & Realigned & High & 9.5 & 1.43 & .10 & 12 \\
\hline 3 & 2 & Original & Low & 2.9 & 2.63 & .19 & 33. \\
\hline 3 & 2 & Original & Medium & 3.8 & 3.00 & .30 & 22 \\
\hline 3 & 2 & Original & High & 7.6 & 4.59 & .71 & 140 \\
\hline 4 & 2 & Realigned & Low & 4.2 & 1.55 & .02 & 9.7 \\
\hline 4 & 2 & Realigned & Medium & 6.2 & 1.55 & .07 & 9.5 \\
\hline 4 & 2 & Realigned & High & 15 & 2.42 & .21 & 50 \\
\hline 5 & 3 & Original & Low & 1.8 & 1.33 & .28 & 12. \\
\hline 5 & 3 & Original & Medium & 3.4 & 1.63 & .22 & 9.7 \\
\hline 5 & 3 & Original & High & 7.4 & 1.76 & .09 & 40 \\
\hline 6 & 3 & Realigned & Low & 1.7 & 2.64 & .10 & 13 \\
\hline 6 & 3 & Realigned & Medium & 5.5 & 2.59 & .34 & 12 \\
\hline 6 & 3 & Realigned & High & 14 & 3.61 & .41 & 31 \\
\hline
\end{tabular}

(fig. 8, p. 12), showing that the DO loss rate in the SOD chambers can increase due to the resuspension of material in the surficial sediments. The resuspension of sediment particles increases the interfacial area of bottom material in contact with the overlying water, resulting in a higher DO loss rate as hypothesized in figure 2 (James, 1974). This resuspension effect probably occurs in the river as well, under the influence of similar or higher water velocities, particularly during storm-like precipitation events or in the high-flow season (November through April). Precipitation, discharge, and DO data from the Tualatin River in figure 9 (p. 13) are consistent with this hypothesis. DO values in figure $9 \mathrm{C}$ correspond with periods of storm-related discharge (figs. 9A and 9B). Because sediment may become suspended during periods of higher water velocity, the velocity generated in an SOD chamber should be as close as possible to the velocity of the overlying water near the sediment-water interface when measuring SOD in an aquatic system.

\section{Velocity and Discharge in the Tualatin River during this Study and in 1992-96}

ADCP readings were obtained in the same reach of river and under similar flow conditions as those when the chamber circulation velocity experiments were conducted. Measurements of near-bottom stream velocity were made at three locations in the study area from river mile 11.7 to river mile 10 . These measurements were averaged and are listed in table 2.

Table 2. Average near-bottom river velocity calculated from acoustic doppler current profiler readings at selected sites in the Tualatin River, Oregon

$[\mathrm{cm} / \mathrm{sec}$, centimeters per second]

\begin{tabular}{lccc}
\hline \multicolumn{1}{c}{ Location } & Date & $\begin{array}{c}\text { Average velocity } \\
\text { (cm/sec) }\end{array}$ & $\begin{array}{c}\text { Standard } \\
\text { deviation }\end{array}$ \\
\hline River mile 10 & $11 / 13 / 01$ & 7.9 & 4.3 \\
River mile 11.0 & $11 / 13 / 01$ & 6.0 & 4.0 \\
River mile 11.7 & $11 / 13 / 01$ & 5.6 & 2.1 \\
\hline
\end{tabular}




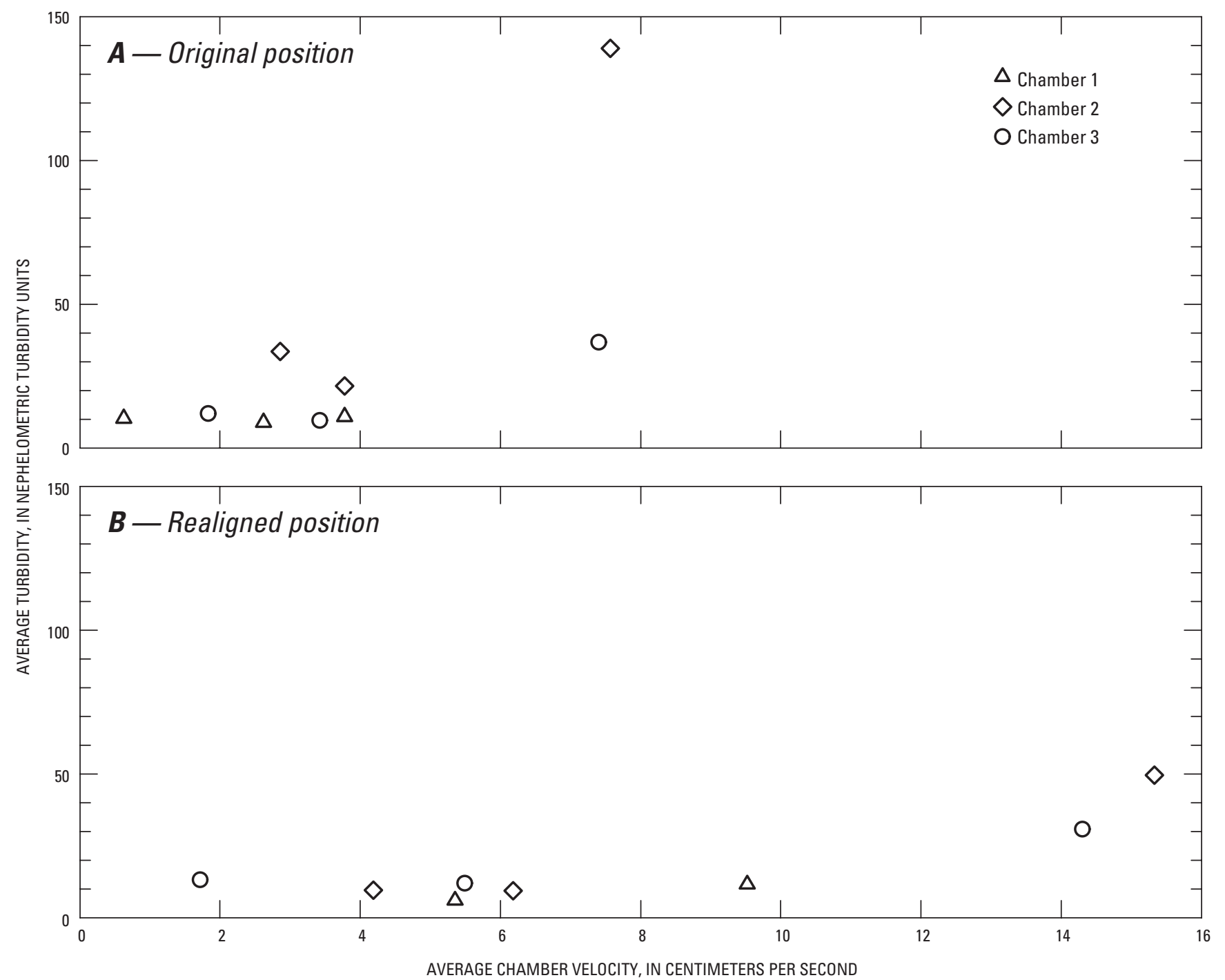

Figure 7. Average turbidity values with corresponding chamber mixing velocities obtained during chamber velocity experiments with diffusers in their $(A)$ original position and $(B)$ their realigned position.

Mean near-bottom river velocities for ADCP measurements at river miles $10.0,11.0$, and 11.7 were $7.9,6.0$, and $5.6 \mathrm{~cm} / \mathrm{sec}$ respectively. The velocity at river mile 10 was in the range where the turbidity data from this study suggest the potential for resuspension of bottom sediments with the diffusers aligned in their original positions; however, flow in the river where the experiments were conducted is not turbulent, and it is likely that the bottom sediments would not be disturbed at that velocity.

Discharge in the Tualatin River during the SOD chamber experiments in August 2000 was similar to that during November 2001, when the ADCP measurements were made (table 3, p. 14); therefore, it is likely that the river-bottom velocities during the experiments were similar to those estimated from the
ADCP measurements. Because discharge in the Tualatin River during most of the 1992-96 SOD measurements (Rounds and Doyle, 1997) was similar to that during these experiments (less than about 300 cfs; U.S. Geological Survey, 1993-97), it is likely that the near-bottom river velocities then were similar as well.

The only exception was in May 1993, when discharge was as much as three times higher than on the other measurement dates. Turbidity data obtained at main-stem sites by Clean Water Services (formerly Unified Sewerage Agency of Washington County) during the May 1993 SOD measurements (Doyle and Caldwell, 1996), indicate that turbidity levels were slightly elevated compared to those on other sampling 


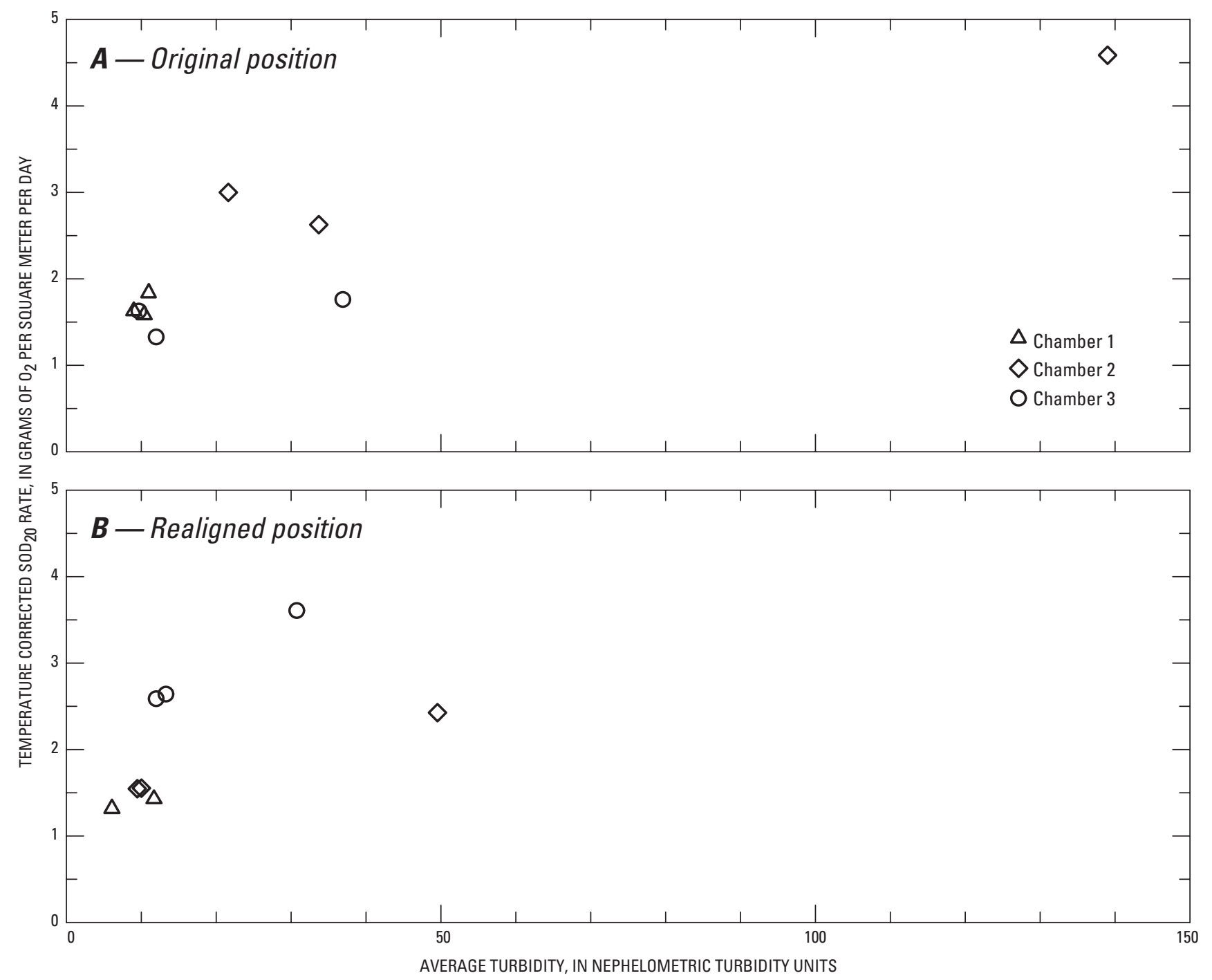

Figure 8. $\mathrm{SOD}_{20}$ rates with corresponding turbidity values obtained during chamber mixing velocity experiments with diffusers in $(A)$ their original position and $(B)$ their realigned position.

dates, but the highest value (9.4 NTU) does not indicate a significant resuspension of bottom materials.

Certainly, the difference between turbidity levels on low-flow sampling dates and the May 1993 values was much less than the differences observed in the chambers during these experiments.

\section{DISCUSSION}

Results of this study show that the near-bottom water velocity has an effect on the SOD rate in the Tualatin River; however, that effect is important only when the velocity is high enough to resuspend the bottom material. The rate of oxygen consumption in the undisturbed sediments appears to be slower than the rate of physical oxygen delivery to those sediments at chamber circulation velocities less than required to resuspend bottom sediments.

Other researchers using cylindrical SOD chambers have measured an increase in oxygen flux at the sediment-water interface as the chamber velocity was increased; this increase in oxygen flux occurred within seconds in most cases (Booij and Sundby 1991). If the dissolved oxygen loss rate in the USGS chambers had been controlled by the rate of transport of oxygen to the sediment-water interface, then any increase in chamber circulation velocity should have increased that transfer rate and caused an increase in the rate of oxygen loss within the chamber. Because the measured 

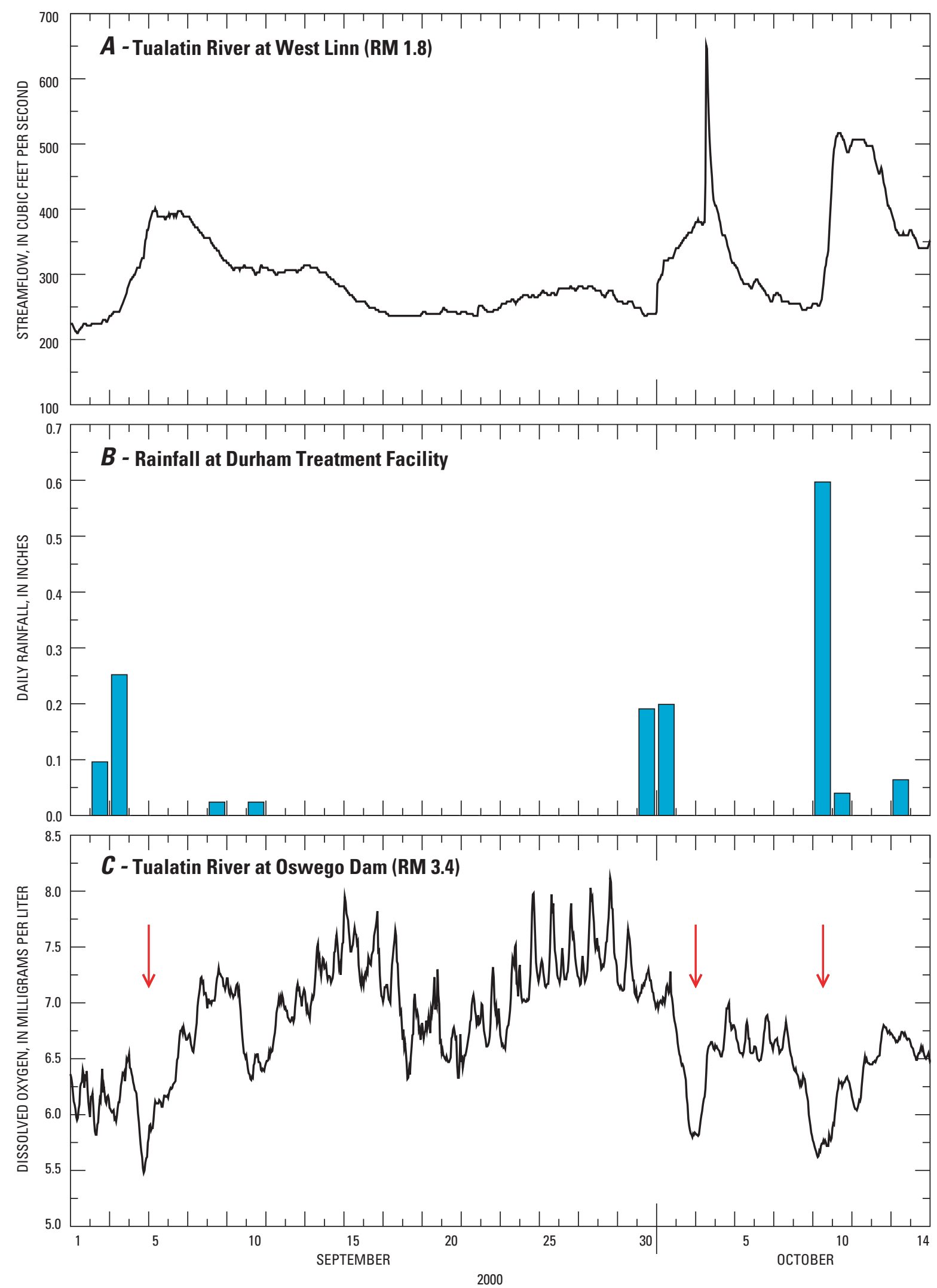

Figure 9. (A) Discharge measurements from the Tualatin River at West Linn (river mile 1.8, USGS station number 14207500), $(B)$ rainfall measured at the Clean Water Services Durham Treatment Facility (USGS station number 452359122454500), (C) dissolved oxygen values measured in the Tualatin River at 0swego Dam (river mile 3.4, USGS station number 14207200), September 1-0ctober 15, 2000 (arrows indicate significant dissolved oxygen decreases following a storm event). 
Table 3. Stream discharge in the Tualatin River during sediment oxygen demand chamber circulation velocity experiments in August 2000 and in November 2001

[Discharge reported in cubic feet per second; RM, river mile; gage, discharge measured at streamflow-gaging station; ADCP, discharge measured with acoustic doppler current profiler]

\begin{tabular}{rccccc}
\hline & $\begin{array}{c}\text { Tualatin } \\
\text { River at } \\
\text { West Linn } \\
\text { (RM 1.8) } \\
\text { (gage) }\end{array}$ & $\begin{array}{c}\text { Tualatin } \\
\text { River at } \\
\text { RM 10 } \\
\text { (ADCP) }\end{array}$ & $\begin{array}{c}\text { Tualatin } \\
\text { River at } \\
\text { RM 11 } \\
\text { (ADCP) }\end{array}$ & $\begin{array}{c}\text { Tualatin } \\
\text { River at } \\
\text { RM 11.7 } \\
\text { (ADCP) }\end{array}$ & $\begin{array}{c}\text { Tualatin River } \\
\text { at Farmington } \\
\text { Rd (RM 33.3) } \\
\text { (gage) }\end{array}$ \\
\hline $8 / 7 / 00$ & 202 & & & & 197 \\
$8 / 8 / 00$ & 205 & & & & 197 \\
$11 / 13 / 01$ & 294 & 200 & 222 & 208 & 195 \\
\hline
\end{tabular}

loss rate did not increase much with increasing chamber circulation velocity at rates less than those that caused sediment to be resuspended, it appears that the measured oxygen loss rate was reflecting oxygen consumption by chemical and biological reactions in the sediment rather than physical transfer of oxygen to those sediments.

The SOD measurement chamber circulation velocity at which sediment resuspsension is likely to occur in the Tualatin River may depend on the orientation of the chamber diffusers. Because resuspension occurred at lower velocities when the diffusers were in their original positions, a condition that created random flow vectors, than when in the realigned position, it is possible that the turbulent flow is able to dislodge sediment particles at lower average chamber velocities. Results of the chamber circulation velocity experiments showed that resuspension was likely to occur at average velocities greater than about $7.5 \mathrm{~cm} / \mathrm{sec}$ with the diffusers in their original positions, whereas velocities of up to about $9.5 \mathrm{~cm} / \mathrm{sec}$ did not cause resuspension with the diffusers in their realigned positions. The amount of resuspension, however, is a function of sediment characteristics as well as water velocity and flow pattern inside of the chamber. Because the original and realigned experiments were performed on different patches of sediment, conclusions about these differences in resuspension are tentative and preliminary.

Because of equipment limitations, SOD rates were not determined for chamber circulation velocities less than $0.6 \mathrm{~cm} / \mathrm{sec}$; it is unknown whether SOD rates decrease at lower velocities due to an inability to transport a sufficient supply of DO to the sediment-water interface (fig. 2). The fact that SOD rates did not decrease significantly when velocities were as low as $0.6 \mathrm{~cm} / \mathrm{sec}$ does not demonstrate that it does not occur, just that the rate of transport of oxygen to the sediments at that circulation velocity is still sufficient to supply oxygen at a rate at least as high as its utilization in the sediments.

Chamber circulation velocity measurements documented here for the original diffuser orientation were likely representative of the mean chamber circulation velocities during 1992-96 SOD measurements obtained in the Tualatin River Basin. Average chamber circulation velocities during 1992-96 appear to have been in the range of $3.5 \mathrm{~cm} / \mathrm{sec}$ to 7.6 $\mathrm{cm} / \mathrm{sec}$, based on results of this study, previous measurements of chamber circulation velocity (Rounds and Doyle, 1997), the fact that the chamber diffuser orientation (fig. 4) was not changed until they were realigned for these experiments, and the fact that the same pumps and chambers were used in both these experiments and in the 1992-96 studies.

Data from Rounds and Doyle (1997) suggest that bias due to sediment resuspension, in which the SOD rates in one or more of the three measurement chambers used at a particular site was different from that in the others, was limited to a small percentage of SOD measurements obtained in the Tualatin River Basin. Examples of this phenomenon can be seen in SOD measurements obtained at Rock and Bronson Creeks on July 18, 1996, and Gales Creek on July 19, 1996 (Rounds and Doyle, 1997).

\section{CONCLUSIONS}

Based on the experimental data collected in this study, the following conclusions can be drawn:

1. At chamber circulation velocities less than those required to resuspend bed sediment, the measured SOD rate was only slightly affected by the circulation velocity, indicating that the rates measured were a reflection of the rate of oxygen utilization by chemical and biological reactions in the sediment rather than the rate of physical transport of oxygen to the sediment-water interface.

2. Measurements by an Acoustic Doppler Current Profiler (ADCP) indicate that typical near-bottom river velocities in the Tualatin River are of similar magnitude to those generated in the chambers used to measure sediment oxygen demand (SOD) from 1992 to 1996. This fact, combined with conclusion (1), suggests that the SOD rates measured with 
those chambers are a good approximation of the SOD in the river.

3. At chamber circulation velocities high enough to resuspend bottom sediments (as evidenced by a large increase in turbidity within the chamber), SOD rates increased anomalously as a result of increased surface area of decomposing material in contact with the water column. This same phenomenon probably occurs in the Tualatin River during storm-runoff events following prolonged periods of low flow, resulting in increased oxygen demand until sediment resuspension ceases.

4. The orientation of the water diffusers in the chambers may have affected the average chamber circulation velocity at which sediment resuspension occurred. When the diffusers were arranged to create a more random mixing pattern within the chamber, the average velocity at which sediment resuspension occurred was less than when the diffusers were arranged to create a circular flow pattern. However, the SOD rates for each diffuser orientation were similar at circulation velocities less than required to resuspend bottom sediments.

5. The potential artifact in measuring SOD rates due to sediment resuspension is large. When measuring SOD rates with this type of chamber, it is important to monitor turbidity during the experiment so that a resuspension bias can be avoided.

\section{REFERENCES CITED}

Booij K., and Sundby B., 1991, Rapid redistribution of oxygen in a sandy sediment induced by changes in the flow velocity of the overlying water: Netherlands Journal of Sea Research, v. 28, no. 3, p. 149-165.

Doyle, M.C., and Caldwell, J.M., 1996, Water-quality, streamflow, and meteorological data for the Tualatin River Basin, Oregon, 1991-93: U.S. Geological Survey Open-File Report 96-173, 49 p. 1 pl., 1 CD-ROM.

Gordon, R. L., 1996, Acoustic doppler current profiler; Principles of operation; A practical primer: San Diego, California, RD Instruments P/N 951-6069-00, 52 p.

Hatcher K.J., 1986, Introduction to sediment oxygen demand measurement, in Hatcher, K.J., ed., Sediment oxygen demand-Processes modeling, and measurement: Athens, Georgia, Institute of Natural Resources, University of Georgia, p. 301-305.

James A., 1974, The measurement of benthal respiration: Water Research, v. 8, p. 955-959.

Kelly V.J., 1997, Dissolved oxygen in the Tualatin River, Oregon, during winter flow conditions, 1991 and 1992:
U.S. Geological Survey Water Supply Paper 2465-A, $68 \mathrm{p}$.

Leopold L.B., Wolman M.G., and Miller J.P. 1964, Fluvial Processes in Geomorphology: San Francisco, California,W.H. Freeman and Company.

Longaker J.J., Poppe W.L., 1986, Laboratory method for measuring S.O.D., Appendix A of Murphy, P.J., and Hicks, D.B., 1986, In-situ method for measuring sediment oxygen demand, in Hatcher, K.J., ed., Sediment oxygen demand-Processes, modeling, and measurement: Athens, Georgia, Institute of Natural Resources, University of Georgia, p. 323.

Mackenthun A.A., and Stefan H.G., 1998, Effect of flow velocity on sediment oxygen demand experiments: Journal of Environmental Engineering v. 124, no. 3, p. 222-230.

McDonnell A.J., Hall S.D., 1969, Effect of environmental factors on benthal oxygen uptake: Journal Water Pollution Control Federation Journal (Research Supplement), August 1969, part two, p. 353-363.

Murphy, P.J., and Hicks, D.B., 1986, In-situ method for measuring sediment oxygen demand, in Hatcher, K.J., ed., Sediment oxygen demand-Processes, modeling, and measurement: Athens, Georgia, Institute of Natural Resources, University of Georgia, p. 307-322.

Nakamura Y., Stefan H.G., 1994, Effect of velocity on sediment oxygen demand, Theory: Journal of Environmental Engineering, v. 120, no. 5, p. 996-1016.

Parkhill, K.L., and Gulliver, J.S., 1997

Discussion-Comparison of two sediment oxygen demand measurement techniques: Journal of Environmental Engineering, v. 122, no. 1, p. 97-98.

Rantz and others, 1982, Measurement and computation of streamflow-Volume 1, Measurement of stage and discharge: U.S. Geological Survey Water-Supply Paper 2175, $284 \mathrm{p}$.

Rounds, S.A., and Doyle, M.C., 1997, Sediment oxygen demand in the Tualatin River Basin, Oregon, 1992-96: U.S. Geological Survey Water-Resources Investigations Report 97-4103, 19 p.

Rounds S.A., Wood T.M., and Lynch, D.D., 1999, Modeling discharge, temperature, and water quality in the Tualatin River, Oregon: U.S. Geological Survey Water-Supply Paper 2465-B 121 p.

Thomann, R. V., and Mueller, J.A., 1987, Principles of surface water quality modeling and control: New York, Harper and Row, p. 291-293.

U.S. Geological Survey, 1993-97, Water resources data for Oregon, water years 1992-96: U.S. Geological Survey Water-Data Reports OR-92-1 to OR-96-1 (published annually).

Whittemore, R.C., 1986, The significance of interfacial water velocity on the measurement of sediment oxygen demand, in Hatcher, K.J., ed., Sediment oxygen demand-Processes, modeling, and measurement: Athens, Georgia, Institute of Natural Resources, University of Georgia, p. 63-74. 
Whittemore, R.C., 1999, Discussion on "Effect of flow velocity on sediment oxygen demand-Comparison of theory and experiments," by Rajalakshmi J.M., and
Stefan, H.G.: Journal of the American Water Resources Association v. 35, no. 5, p.1277. 

